\title{
- t.....
}

\section{「強レーザー場による分子制御特集号によせて 一強光子場科学研究の現状と将来展望一}

\author{
山内董 \\ 東京大学大学院 理学系研究科化学専攻 (†113-0033 東京都文京区本郷7-3-1)
}

\section{Preface to Special Issue on Control of Molecules in Intense Laser Fields - Current Research Scene of Intense Laser Science and its Future -}

\author{
Kaoru YAMANOUCHI \\ Department of Chemistry, School of Science, the University of Tokyo, 7-3-1 Hongo, Bunkyo-ku, Tokyo 113-0033
}

(Received August 28, 2007)

\begin{abstract}
Recent development of high-power ultrashort-pulsed laser technologies has made it possible to increase the light field intensity as high as the magnitude of a Coulombic field within atoms and molecules, and afforded the basis of the birth of the new interdisciplinary research field called "Intense Laser Science." It has become possible to control molecular processes by intense laser fields, and a new research area of "Attochemistry" is about to emerge.
\end{abstract}

Key Words: Intense laser fields, Control of molecular processes, Ultrafast hydrogen migration, High-order harmonics, Attoseccond chemistry

1.はじめに

原子や分子は，光を吸収することによって励起状態とな る.このときの光の役割は, 物質を「物質のある量子状態」 から「物質の別のある量子状態」に変えることである。この とき，重要なことは，「物質が持っている性質」に対して， 光は何の影響も与えていないということである．当たり前 のことのようであるが，光がもっと強くなるとは，状況は 異質なものとなる，光は電磁波であり，その電場は時間と 共に振動する。この振動する電場の大きさが, 原子や分子 のなかで電子が置かれている静的なクーロン場の大きさと 同じくらいにまで大きくなると, 電子は光によって摇すら れるようになる。このときの「物質が持っている状態」を光 から切り離して考えることはできない.このような強光子 場においては, 物質は光が存在している間, 「光と物質が 混ざり合った状態」にあると考えることができる.

超短パルスレーザー技術の進歩は, フェムト秒領域の 極めて短い時間であれば，原子，分子内のクーロン場の 大きさを凌駕する強光子場を生成することを可能とし た.このことが意味することは, そのパルス状の光が存 在する時間は，分子は「光と物質が混ざり合った状態」にあ る。したがって，パルスの形状や強度を変化させること が出来れば，物質の動的な挙動を制御することが可能と なる. 分子の場合, 化学結合を形作る電子が光電場に よって摇すられるため, 化学結合の切断や生成を光に
よってコントロールするというシナリオが成り立つ. レーザー光の出現以来, レーザー光を用いた化学反応 は，化学の分野における一つの目標であった。しかし， 分子内で極めて速く進行する分子内エネルギー再分配過 程などの緩和過程のために, 選択的な化学結合の切断は 困難であった．弱い光では分子の支配から逃れることが 困難であった。つまり，強光子場下において，光による 化学反応の能動的な制御がはじめて可能になったと言う ことができる。

Fig. 1に, 強光子場科学の分野における研究対象について の概観を示した．この図において， $1 \mathrm{PW} / \mathrm{cm}^{2}\left(1 \times 10^{15} \mathrm{~W} /\right.$ $\left.\mathrm{cm}^{2}\right)$ の強度を中心として, その上下の3桁程度の間はクー ロン領域と呼ばれる。この領域では, 分子内のクーロン場 の大きさと, 分子がその領域においてさまざまな特異なダ イナミクスを示すことが明らかとなっている. 例えば，比 較的レーザー場の低い領域 $\left(1 \mathrm{TW} / \mathrm{cm}^{2}=1 \times 10^{12} \mathrm{~W} / \mathrm{cm}^{2}\right)$ に おいて分子はレーザー電場の方向に向きを揃える配向や配 列という現象がおこり，レーザー場が大きくなり $1 \mathrm{PW} / \mathrm{cm}^{2}$ に近づくと分子の構造が光子場の下で大きく変形するよう になる.さらに, 光電場によるトンネルイオン化現象が進 み, 分子系は多価イオンとなり, クーロン爆発と呼ばれる 現象が起こることが知られている．このようなダイナミク スは，光子場によって分子の持っていた分子内のポテン シャルが大きく歪むことによって説明できる.

このように, 強光子場中では, 原子や分子は光によっ 


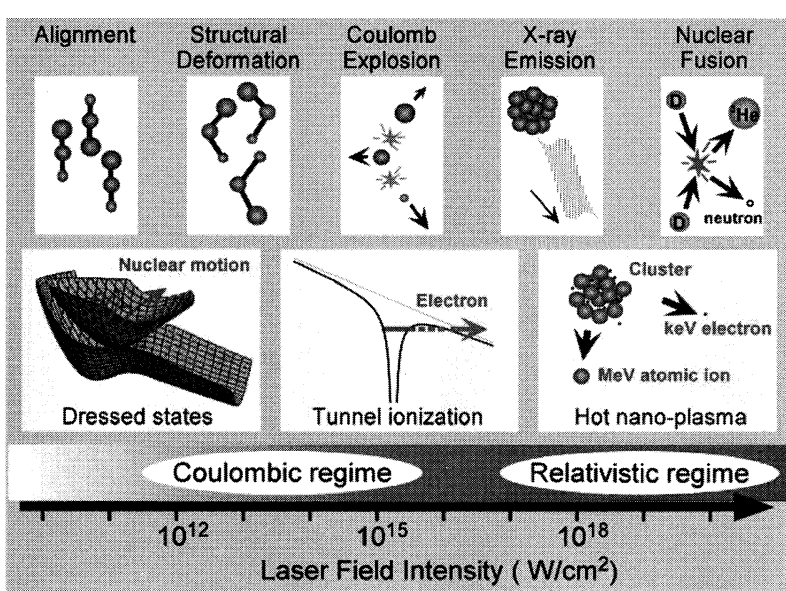

Fig. 1 Variety of phenomena occurring in ultrashort intense laser fields. ${ }^{1)}$

てその性質を大きく変化させ，光と物質が混合した状態 が形成される. 光が存在している間は, 「光が存在しない ときの物質とは全く異なった性質をもつ状態」が形成され ることになる。これは，概念的に，これまでには無いカ テゴリーの研究領域がそこに開けたことを意味してい る. 強光子場科学は, 弱い光を扱う科学とは質の異なる ものを対象とした，新しい学術領域なのである.

レーザー電場がさらに大きい $1 \mathrm{EW} / \mathrm{cm}^{2}\left(10^{18} \mathrm{~W} / \mathrm{cm}^{2}\right) を$ 超える領域は相対論領域と呼ばれている。この領域で は, 光電場によって加速された電子が, 光速に近く加速 されローレンッカによって大きく影響を受けるようにな る。クラスターや固体ターゲットにレーザー光を照射し 相対論領域の強光子場を生成すると, 高速 $(\mathrm{keV} \sim \mathrm{MeV})$ の 電子やプロトンが発生することが知られている。また, ピコ秒領域の短パルスのX線を発生させることができる。 このように高エネルギー荷電粒子や高エネルギーの光子 の発生は総じて量子放出と呼ばれている。これらの量子 放出現象が，ピコ秒オーダーの時間幅で起こるために, 量子放出を利用して, 物質の時間変化を超高速で追跡す ることも可能となっている. 例えば, 量子放出として得 られたX線を超短パルス光源として，X線回折を時間分解 で行い固体内のダイナミクスを追跡するなどの研究が行 なわれている．また，重水分子からなるクラスターから は中性子の発生が確認されるなど, 相対論領域では, 光 子場による核反応の誘起が可能となる。

本稿では, クーロン領域に扔ける研究展開, 特に, 強 光子場下に扔ける分子の特異な振る舞いについて焦点を 当てて, 最新の強光子場科学の一端を紹介する.

\section{2. 強光子場における3原子分子系の大規模構造変化}

私の研究グループでは, 強光子場下に执いてイオン化 を経てクーロン爆発にいたる分子のダイナミクスを, 独 自の実験手法を導入することによって研究してきた。例 えば, イオン検出法として位置敏感型検出器を用いたコ インシデンス運動量画像 (CMI; Coincidence Momentum Imaging)法を導入し，それまで見ることのできなかった一
つ一つの多価イオンがどのように分裂するかを明らかに できるようになった。コインシデンス運動量画像法を, 強光子場中の分子のダイナミクスを研究するために用 い，強光子場によってクーロン爆発を起こす $\mathrm{CS}_{2} や \mathrm{~N}_{2} \mathrm{O}$ どの分子のコインシデンス運動量画像の観測を成功させ た。 その結果, 強光子場下でおこる大規模な分子の構造 変形過程が明らかになった。

Fig. 2は，CMI法によって得られた $\mathrm{CS}_{2}{ }^{3+}$ のCMI図であ る.この場合, 二つのS $\mathrm{S}^{+}$イオンの運動量ベクトルを $p_{1}, p_{2}$ とし, 中心の $\mathrm{C}^{+} の そ れ を p_{3}$ とするとき, 横軸を $p_{1}$ と $p_{2}$ の成 す角とし，縦軸を $p_{12}=\left|p_{2}-p_{1}\right|$ としている. この図から， 直線型で解離する場合に相当する $p_{12}=0$ の場合, 変角方向 に広い分布があることがわかる。この $p_{12}=0$ を中心とする 分布は, 二つのC-S結合がともに広がり，2つの結合の解 離にいたるダイナミクスであり「協奏的」過程である．さら に, CMI図には特徵的な「腕」の構造を見出すことができ る。これは, $\mathrm{CS}_{2}{ }^{3+}$ が一度, $\mathrm{C}^{+}$と $\mathrm{CS}^{2+}$ に解離し, その後, 2原子分子イオンが回転運動をはじめ, その後に $\mathrm{C}^{+}+\mathrm{S}^{+}$に 解離するという，「段階的」解離を表している.

量子力学の支配する分子系のダイナミクスを巨視的な 画像上の一点一点に対応させるというこのCMI法の出現に よって, 強光子場下での分子ダイナミクスへの理解は, 一段と深まることとなった，例えば，最近の例では，CMI 法によるアセトニトリル $\left(\mathrm{CH}_{3} \mathrm{CN}\right)$ やメタノール $\left(\mathrm{CH}_{3} \mathrm{OH}\right)$ の研究から, 強光子場下で分子内の水素が高速でマイグ レーションすることが示された。ささらに，ポンプープ ローブ法によって, $\mathrm{CS}_{2}$ の構造変化が強光子場に扔いてど のように進行するかについての明瞭な知見が得られてい る。また，メタノール分子からの $\mathrm{H}_{3}{ }^{+}$の生成についても CMI計測が行われ, 確かに, $\mathrm{H}_{3}{ }^{+}$と $\mathrm{COH}^{+}$が対となって生成

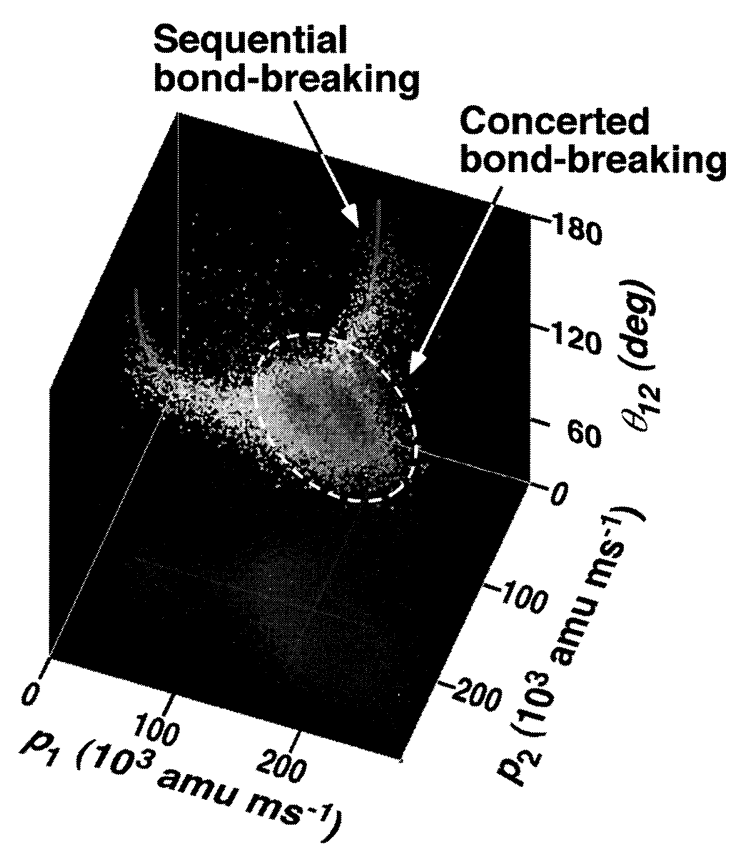

Fig. 2 Three-dimensional momentum distribution map of the atomic fragment ions ejected through the three-body Coulomb explosion of $\mathrm{CS}_{2}{ }^{3+} ; \mathrm{CS}_{2}{ }^{3+} \rightarrow \mathrm{S}^{+}+\mathrm{C}^{+}+\mathrm{S}^{+}$, in ultrashort intense laser fields $\left(0.2 \mathrm{PW} / \mathrm{cm}^{2}, 60 \mathrm{fs}\right){ }^{2)}$ 
することが示されるなど, 超高速水素移動を伴うダイナ ミクスについての理解がCMI法によって格段に高められて いる. この $\mathrm{H}_{3}{ }^{+}$の生成は, 強光子場下での化学結合の組み 換え反応の例として注目されている。すなわち，メ夕 ノールの持つメチル基3つのC-H結合が切断され, $\mathrm{H}_{3}{ }^{+}$の3 つのH-H結合が生成されたのである.

3原子分子など, 小さな分子の幾何学的な構造が強光子 場下で大きく変化することは, すなわち, 直線型の分子 が屈曲型に，また，屈曲方の分子が直線型になるという ことは, 変角方向へのポテンシャルのうち, 直線状態に 最小值をもつポテンシャルと, 屈曲位置に最小值を持つ2 重井戸型のポテンシャルが，強光子場によってドレスト 状態を生成して混合しあった結果であると解釈された. この解釈が正しいことは, 東北大学の河野裕彦教授と藤 村勇一教授の研究グループが, 独自に開発した時間依存 断熱状態法によって, $\mathrm{CO}_{2}$ 分子について, その強光子場に おける分子形状の変化を理論的に追跡することによって 確かめられている。

\section{3. 炭化水素分子における超高速水素分子ダイナミクス}

炭化水素分子の場合には, 強光子場中において, 分子内 の水素原子が，極めて高速にマイグレーションすること， そして，それと同時に，水素原子の3量体イオンが効率よ く発生することなど，新奇な現象の存在が，我々の研究か ら明らかとなった。その後，一連の炭化水素分子について 研究を進めたところ，メチル基の無い炭化水素分子であっ ても，水素の数が十分にあれば，強光子場との相互作用の 結果，水素原子 3 量体のイオンが効率よく生成する場合が 多いことが明らかとなった。これは，分子内を水素が極め て自由に動き回ることを示すものであった。

そして，コインシデンス運動量画像法によって，メ夕

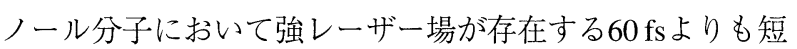
い時間において分子内の水素原子が炭素原子や酸素原子 のまわりを駆け巡ることを示した(Fig. 3)ことは, 断熱近 似によって記述されてきた分子の描像では, その現象を 記述することができないことを示している。 それはすな わち，水素原子，あるいはプロトンが，強光子場におい て動き回るため, その状態を記述する場合，水素原子の 位置を止めた上で想定する通常の断熱ポテンシャルが全 く意味を持たなくなるためである，電子だけでなく，プ ロトンについても別格に扱う新しい電子状態の記述方 法, あるいは, 断熱近似を超えた新しい理論を構築する ことの必要性が明らかになった。

さらに，メタノールの3体解離反応においては，メチル 基の水素原子が，分子の骨格を移動しOH基に向かってい く様子を，コインシデンス画像のスナップショットの形 として捉えられることに成功した。このように, 強光子 場下に㧍ける水素原子あるいはプロトンの超高速ダイナ ミクスの存在は, プロトンの移動を強光子場で制御し, それを骨格の化学結合の切断にいざなうことが可能であ ることを示しており，これからの新しい反応制御技術の 基礎を与えると考えられる.

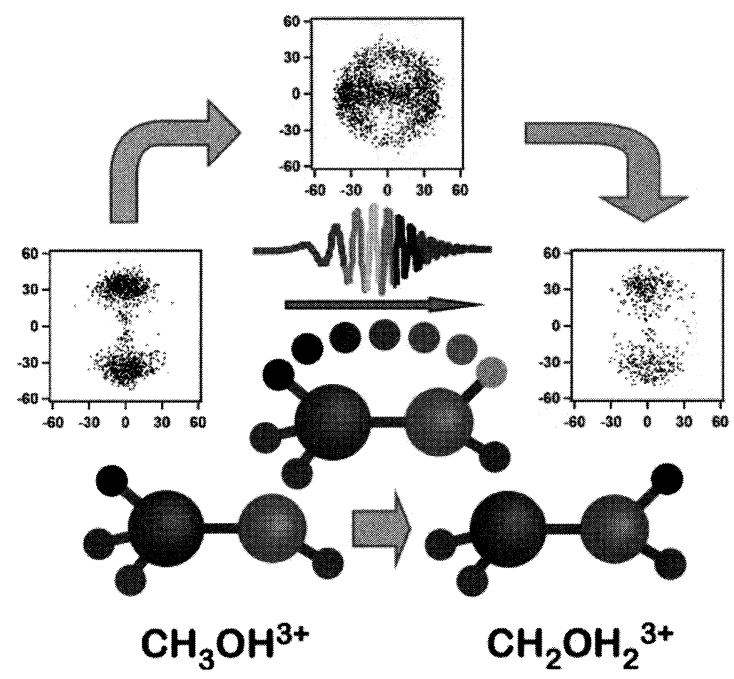

Fig. 3 Ultrafast hydrogen migration processes occurring within a methanol molecule. It was revealed from the CMI measurements that hydrogen atoms migrate extensively with in the ultrashort time duration shorter than $60 \mathrm{fs}^{3)}$

\section{4. 反応制御の実現}

強光子場下において, 分子はイオン化の後, その化学 結合が切断される，その際，どの結合を切断するかを制 御できるかどうかは, 強光子場科学における一つの課題 であった。レーザー電場が弱いとき，分子は光を吸収し 電子励起状態に励起される。もし，その状態のエネル ギーが結合エネルギーよりも高ければ，その化学結合が 切断されるが, どの化学結合が切断されるかは, 基本的 には最初に準備される量子状態が決めることになり, 光 パルスをデザインするかどうかには，その結果は依存し ない。すなわち，分子内で高速に起こるエネルギー再分 配過程が，反応を支配する。しかし，強光子場の場合に は, 分子の電子基底状態のポテンシャルと解離性の電子 励起状態のポテンシャルが, 光の電場を通じて混ざり合 い, 光電場の振幅の大きさ, あるいは, 光の強度の時間 変化に依存して, そのポテンシャルの実効的な形状が変 化する. したがって, 光パルスの強度や形状, パルス内 の周波数分布や位相によって, その光ドレスト状態のポ テンシャルの形状は大きく変化する. すなわち, 光に よって化学結合の切断をコントロールすることが可能と なる．これは，弱い光では成しえなかったことである.

我々は, 慶応大学の神成文彦教授の研究室と共同実験を 行い，エタノールを強光子場にさらし，1価のカチオンの 状態におけるC-C結合の解離と, C-O結合の解離の分岐比 を，強光子場をデザインすることによって制御することを 試みた。フーリエ限界パルスにおいては，C-C 結合の解離 が支配的であったが，超短パルスレーザー光をチャープさ せて，そのパルス幅を約 $1 \mathrm{ps}$ まで広げたところ, C-O結合 の解離の分岐比が数倍も増加することが示された(Fig. 4). この顕著な現象についての報告は, 最も基本的な反応制御 の実験例として, 広く知られている.この結果は, 強光子 場によって, 光ドレスト状態のポテンシャルが生成し, そ 
の形状がC-O結合の方向に核の波束をガイドするためであ ると解釈された。そして，それをさらに確認するために， 2重パルス，3重パルス，4重パルスの実験が行なわれ，連 続して長い時間強光子場にさらされる程, C-O結合の解離 の分岐比が大きくなることが示された.

この結果を受けて，東北大学の河野・藤村グループが 時間依存理論計算を行い，1価のカチオンにおいて，エ夕 ノールの電子基底状態のポテンシャルと解離性の電子励 起状態の幾つかのポテンシャルが混ざり合うこと, そし て, C-O結合の解離が起こるためには, C-C結合の解離を 起こすよりも長い時間強光子場に分子をさらすことが必 要となることを示し, 実験による推測が正しいものであ ることが理論的に明らかとなった.

我々はこの理論研究を受けて, 波長依存性についての研 究を行い, 紫外域の波長領域 $(400 \mathrm{~nm})$ においては, その反 応制御性がより高くなることが明らかとなった。このよう な, 理論と実験の相互の連携は, 強光子場科学の分野のフ ロンティア開拓には極めて役立つものである.

\section{5. サブ10フェムト秒への挑戦}

超短パルスのレーザー幅が30 - 100 fsであれば，この時 間内に分子は核の位置を十分に変化させることができ る. 実際, 骨格の構造が大きく変化することや, 分子内 の水素原子が光の場の中で動き回ることなどがそのこと を示している．このとき，超短パルスレーザー光のパル ス幅をさらに短くした場合，分子系がどのように応答す るかは, 未知の領域であった。

我々は, チタンサファイア増幅器からのレーザー出力 $(800 \mathrm{~nm})$ を, Neガスが封入された中空ファイバへ導入 し, 自己位相変調により広帯域化し, その後, チャープ

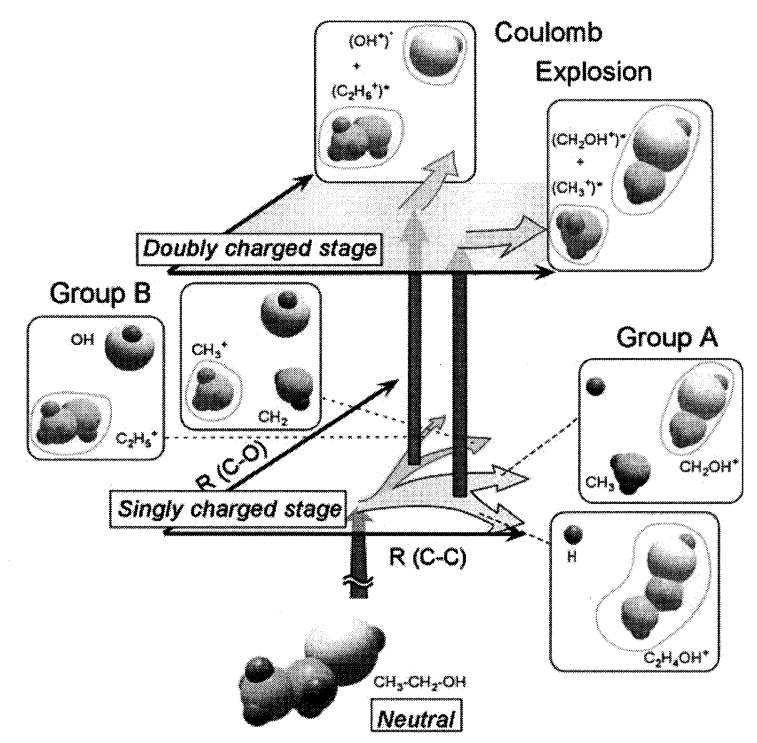

Fig. 4 Selective chemical-bond breaking in ethanol $\left(\mathrm{C}_{2} \mathrm{H}_{5} \mathrm{OH}\right)$ in ultrashort intense laser fields. The temporal duration of the laser pulses needs to be stretched to as much as $760 \mathrm{fs}$ in order to maximize the yield ratio of the $\mathrm{C}-\mathrm{O}$ bond breaking with respect to the $\mathrm{C}$ C bond breaking. ${ }^{4)}$
ミラーを用いて分散補償した後，6fs（FWHM）までパルス 圧縮し分子線に集光し, 飛行時間型質量分析法, およ び，コインシデンス運動量画像法によってそのダイナミ クスを明らかにした。このような極超短パルス光におい ては, 周期的に変化する光電場が $2-3$ サイクルしか含まれ ないために, few-cycleパルスと呼ばれている. 我々は, 分 子系として, $\mathrm{H}_{2} \mathrm{O}$ おびエ夕ノールを選んで, その解離過 程を追跡したところ，この極超短パルス領域では，パル ス幅の変化とともに分子の解離ダイナミクスが鋭敏に変 化することが明らかとなった。

水分子の場合には, フラグメントイオンの運動エネル ギー分布のパルス幅依存性から, 超短時間 (6-22fs)内に 構造変形と電荷分離過程が協奏的に起こることが明らか となった。 また，エ夕ノールの場合には分子内の水素移 動が解離フラグメントの異方性に影響を与えることが示 されるなど，極超短パルス光と分子系の相互作用は，30$100 \mathrm{fs}$ 程度の比較的長いパルス光の場合と質的に異なるも のであることが示された。この研究は, NTT物性科学基礎 研究所の中野秀俊グループリーダの研究室との共同研究 として行なわれたものである。

\section{6. アト秒領域への挑戦}

究極の短さの光と分子の相互作用を解き明そうすると き，光の波長そのものを短くする必要がある．なぜなら ば，たとえfew-cycleパルスを作ったとしても，光の波長が $800 \mathrm{~nm}$ であれば，そのサイクルは $2.7 \mathrm{fs}$ であることから， 5- 7 fsが限界の短さである。 もし, 波長を真空紫外や軟X 線領域とすれば，アト秒領域のパルスを生成することが 可能となる．それ程までに短くした光パルスと分子の相 互作用はどのようなものとなるだろうか。 また，そのよ うなアト秒パルスを用いれば，分子内の電子の運動に伴 う現象を追跡することも可能となると期待される.

我々は, 理化学研究所の緑川克美主任研究員のグルー プとの共同研究として, 分子とアト秒パルストレインと の相互作用に関する基礎的な研究を開始した.フエムト 秒レーザーをガスセル中のXeターゲットに集光すること によって高次高調波を発生させた.2枚の $\mathrm{Si}$ 平行平板基板 で構成されるビームスプリッターで高調波ビームを2本に 分割した後，パルスバルブより分子線として導入した分 子線に集光照射し, 生成した原子フラグメントイオンを 飛行時間型質量分析器で検出した．窒素分子の場合, 一 方の $\mathrm{Si}$ 基板をピエゾを用いて微動させ，2本のビームに遅 延時間を設けることによって, 窒素原子イオンのシグナ ルの変化を追跡したところ, アト秒パルストレインの自 己相関測定が測定された。 その結果，アト秒パルストレ インのパルス幅が300アト秒以下であることが明らかと なった．分子そのものがアト秒パルストレインのキャラ クタリゼーションのための極めて有効な媒質であること がはじめて明らかとなった。 


\section{7.これからの展開}

我々は, この 10 年程の間に, 強光子場科学の分野の研究 を進めてきたが，上記の他に，パルス電子回折法による強 光子場下にある $\mathrm{CS}_{2}$ 分子の電子回折像の測定の他, 固体二 酸化炭素への強レーザー照射に伴う高エネルギーイオンの 量子放出現象の観測などの実験を行なってきた。また，夕 ンデム型質量分析装置を用いて，サイズ選別されたアニリ ン・アンモニアクラスターイオンを強光子場下にさらすこ とによって, クラスターサイズによって, 特異な化学反応 が進行することを見出すなど, 新しいクラスター内反応を 見出した。 また，デバイ遮蔽モデルに基づいたレーザープ ラズマ中の多電子原子の電子状態についての理論計算や, 強光子場の偏光特性を利用した多原子分子の空間配向の制 御などの理論研究を進めてきた.

強光子場分子科学に関する研究は, 先端超短パルス レーザー光源の発達とともに飛躍的に豊富化した. しか し, 短波長領域において強光子場を実現することは困難 である。例えば, $60 \mathrm{~nm}$ 付近の場合, 高次高調波によって 達成できるレーザー電場の世界記録は, 緑川研究室にお

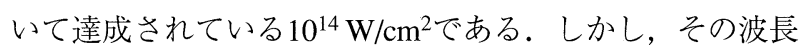
領域での強光子場とみなされるレーザー場の強度は $10^{16}$ $\mathrm{W} / \mathrm{cm}^{2}$ 以上である，現時点のレーザー技術では，それを達 成することはできない，ところが，理研が播磨に建設し たX線自由電子レーザーを用いれば，その強光子場を 60 $\mathrm{nm}$ において発生することが可能となる。短波長領域にお ける強光子場科学は, 先端レーザー光源ばかりでなく,

XFEL装置を活用することによって, さらに飛躍的に発展 するものと思われる，我々は，文部科学省「平成18年度 $\mathrm{X}$ 線自由電子レーザー利用推進研究課題」として,「XFEL光 による分子・クラスターの構造とダイナミクス」に関する 研究を先端レーザー開発の研究グループと連携の下に進 めている. 今後, 短波長領域の強光子場科学は新しいフ ロンティアになると期待される.

日本では, 強光子場科学の持つ新しい可能性に注目し た研究者が集まり, 文部科学省科学研究費補助金・特定 領域研究「強レーザー光子場における分子制御」を平成14年 秋に発足させた. 物理, 化学, レーザー工学の領域の 40 を超える研究グループが, 学際的な取り組みを, 4年間に わたり展開し, 強光子場科学が大きく発展した。また, 強光子場科学分野の国際的な規模での振興に寄与するこ とを目的として, 平成15年に, 産学連携の懇談会「強光子 場科学研究懇談会」(JILS: Japan Intense Light Field Science Society) www.jsps.jpが設立され, 学際的な研究交流を行っ ている.また, 日本の強光子場科学を支える研究者とJILS が中心となって, 毎年, 主に海外にて, “International Symposium on Ultrafast Intense Laser Science” www.isuils.jpを開 催している.

強光子場科学の近年の研究展開については, 文献5)の III-3節に当時までの研究の最前線が簡潔にまとめられてい る. 強光子場科学の全般については, 文献6)に分かりや すい紹介がまとめられている。一方，平成18年から， “Progress in Ultrafast Intense Laser Science”（文献7），8））の
刊行が開始され, 日本, 欧米, アジアにおける強光子場 科学の第一線での研究展開が紹介されている.

本特集では, 強光子場科学の分野の第一線で活躍する日 本を代表する研究者の方々に, 研究領域の最前線を紹介す るとともに，これからの展開について紹介していただい た. 強光子場科学は, ここに紹介したように, 新しい学際 的な研究分野である. 従来の学問の枠を超えて研究を展開 する意欲のある若手研究者の参加によって，この分野のフ ロンティアはますます広がっていくことと思われる.

\section{謝 辞}

ここで紹介した研究は, 主に文部科学省特定領域研究 「強レーザー光子場における分子制御」(平成14〜17年度)の 期間およびそれ以降に行われたものである。その間に 我々の研究プロジェクトに携わった若手研究者には, 研 究室を離れ，それぞれ独自の方向で研究を開始している 者も多い. 菱川明栄 (分子研), 佐甲徳栄 (日大), 星名賢 之助 (新潟薬科大学), 板倉 隆二(原研) は, 研究室スタッ フとして, Peng Liu (SIOM, China) は博士研究員として研 究を推進してくれた。 また, 長谷川宗良(分子研), 加藤 景子 (物材研究機構), 古川裕介 (大阪大学), 寺本高啓 (電 気通信大学) は大学院学生として研究を推進してくれた. また, 現スタッフの帰家令果, 沖野友哉, 加藤毅, 大 学院生の竹本典生も研究推進に尽力してくれた. これら の研究室の旧メンバー, 現メンバーに感謝する。そし て, 河野裕彦 (東北大学), 神成 文彦 (慶応義塾大学), 中 野秀俊 (NTT物性科学基礎研究所), 緑川 克美 (理化学研 究所), 柳下明 (高エネルギー加速器研究機構)の先生方に は，共同研究を通じて特にお世話になり多くを学ばせて いただいた。ここに先生方の御支援と御協力に感謝す る.

最後に，お忙しい中この特集号に寄稿してくださっ た, 中島信昭先生, 河野裕彦先生, 緑川 克美先生, 中村 一隆先生, 神成文彦先生に, そして, 本特集号の企画を してくださった中野秀俊先生に感謝する. この強光子場 科学の発展を支えてくださった, 特定領域研究のメン バーに, 厚く御礼申し上げる。

\section{参考文献}

1) K. Yamanouchi: Science 295, (2002) 2659.

2) A. Hishikawa, H. Hasegawa, and K. Yamanouchi: Chem. Phys. Lett. 388, (2004) 1 .

3) T. Okino, Y. Furukawa, P. Liu, T. Ichikawa, R. Itakura, K. Hoshina, K. Yamanouchi, and H. Nakano: Chem. Phys. Lett. 423, (2006) 220.

4) R. Itakura, K. Yamanouchi, T. Tanabe, T. Okamoto, F. Kannari: $J$. Chem. Phys., 119, (2003) 4179.

5) 強光子場科学研究懇談会「光科学研究の最前線」, (2005).

6) 強光子場科学研究懇談会「強光子場科学の最前線 1」, (2005).

7) K. Yamanouchi, S. L. Chin, P. Agostini, and G. Ferrante: Progress in Ultrafast Intense Laser Science I, Eds., Springer Verlag (2006).

8) K. Yamanouchi, S. L. Chin, P. Agostini, and G. Ferrante: Progress in Ultrafast Intense Laser Science II, Eds., Springer Verlag (2007). 